\title{
Exploring the Indian Tradition of Nonviolent Communication
}

\author{
Vedabhyas Kundu \\ Programme Officer, Gandhi Smriti and Darshan Samiti, New Delhi, India \\ Corresponding author: vedabhyas@gmail.com
}

Received: 22 Sept., 2020

Revised: 23 Nov., 2020

Accepted: 16 Dec., 2020

\begin{abstract}
At a time when the world mired by increasing cases of hate speech and action, intolerance and xenophobia, it is critical that there are efforts to re-look at our communication ecosystem. Unhealthy and dysfunctional communication ecosystems lead to conflicts and intolerance. In this backdrop, the endeavour should be to incessantly work for a communication ecosystem which is healthy and brings people together. It is time that efforts - at individual, local, national and international level be made to help evolve a nonviolent verbal communication ecosystem. While different societies across the world have inherent values to encourage nonviolent verbal communication, it would be prudent to look at the Indian tradition. This paper tries to explore how nonviolent verbal communication has been an integral part of Indian values and ethos. After delving on the ancient traditions of nonviolent communication, the paper tries to analyze the Gandhian model of nonviolent communication which has major traction at the global level.
\end{abstract}

Keywords: Nonviolent communication, Indian tradition of nonviolent communication, Gandhian model of nonviolent communication, Healthy communication ecosystem

Ahimsa is not causing pain to any living being at any time through the actions of one's mind, speech or body.

$$
\text { - Śāndilya Upanisad }
$$

This perspective of ahimsa in the Śāndilya Upanisad contributes to the understanding of nonviolence in Indian tradition. Nonviolence is a wide concept encompassing the actions of one's mind, speech and body. Right communication and the language that we use have been an important issue of concern in Indian intellectual traditions over the ages. If we try to understand the origin of speech, the starting point of our communication, as per the Vedic traditions, we could trace it back to the Goddess Vac, who is called the Mother of the Vedas.

The importance of thoughts and the pluralistic form of the communication process in ancient Indian tradition have been captured by this verse from the Rig Veda (1.89.1): ā no bhadrāh kratavo yantu viśvato (let many noble and auspicious thoughts come to us from all over). It can be argued that the quest for truth in our communication process through a reconciliation of different ideas and views has been an integral part of the Hindu thought and traditions. The essence of harmonious dialogue in arriving at truth has also been underlined in several writings like this Sanskrit proverb, 'vāde vāde jāyate tattvabodha' (through continuous dialogue alone one arrives at the truth).

The importance of words that are used has been

How to cite this article: Kundu, V. (2020). Exploring the Indian Tradition of Nonviolent Communication. Int. J. Peace, Edu. Dev., 8(02): 81-89.

Source of Support: None; Conflict of Interest: None की ब 
underlined in Maitrī Upanisad which says, "Words cannot describe the joy of the spirit whose spirit is cleansed in deep contemplation, who is one with his/her own Spirit (of Ahimsa). Only those who experience this joy know what it is" (Tiwari 2011).

Further, if we look in-depth at the Buddhist and Jain traditions, we will realize how important was nonviolent verbal communication as an integral part of peaceful co-existence in ancient Indian traditions. These underlines on how communication and the notion of human interconnectedness, be it with fellow beings, nature or other livings, are intertwined.

Meanwhile in modern times we have had philosophers like Swami Vivekananda who highlighted this Indian tradition of nonviolent communication.

One of the greatest proponents of nonviolent communication at the global level has been Mahatma Gandhi. His approach of nonviolent communication is a beacon light for any nonviolent action and constitutes an important strategy for nonviolent resolution of conflicts. He too underlined the essence of human interconnectedness as a prerequisite for any nonviolent action.

An important aspect that needs to be grasped while looking at different traditions- whether ancient or contemporary which has been furthered by peace apostles like Gandhi is the all-encompassing nature of nonviolent communication. It is holistic in nature as it covers verbal, nonverbal and symbolic communication, our thoughts and perspectives. Nonviolent communication covers not only the communication with ourselves and other human beings but also our communication with nature and other living beings.

This descriptive study, while delving on the ancient Indian tradition, will also cover in-depth the Gandhian model of nonviolent communication. This will underline the fact how nonviolent communication is an integral part of Indian ethos and ethical system.

\section{Nonviolent communication in ancient Indian tradition}

Sondhi (2020) talking about several Vedic literatures point out how these reveals on how Brahma (the Absolute) identifies with language (śabda). "For instance, The Asya Vamiya Hymn of Rishi Dirghatamas in Chapter 1 of Rig Veda talks of how the ultimate abode of language is Brahma. Here, language is described as something which is the peak of the universe."

Agrawala (1963) talking about the hymn notes, "Here language is related to cosmic order and is understood as the idea of the word as distinct from the spoken word. The spoken word is a limited manifestation of the inner word that reveals the truth." Thus, the Asya Vamiya Hymn says that Gaurir mimaya salilam takshati, the vibration of speech creates or fashions out the manifold forms out of the waters of the infinite ocean of the ultimate Reality, Sondhi adds. Again, for instance, Agrawala (1963) points out that in Chapter 10 of Rig Veda, hymns 71 and 125 establish the significance of speech and language for the thinkers in Vedic times. Further, he talks about Hymn 71 which speaks of the spotless treasures hidden in speech which are disclosed when there is affection in the utterances.

Saraswati (2015, p. 809-15) describes the Vedic traditions and the importance given to speech or communication. In this context, Sondhi (2020) notes, "People with wisdom use speech that wins them friends. Only those who make effort can speak and hear good speech. A person who has not understood the essence of speech can only utter words that are hollow. Good speech comes to those whose action is good and who do not disown friends."

Meanwhile, Sondhi (2020) talks of Hymn 125 of the Rig Veda which also known as Vāk Sukta, regarding which he points out, "In this extensive hymn dedicated to speech goddess, language is considered worthy of worship, and it is seen as energy coexistent with every object in this universe. It is considered as a sustainer of life, a source of success and riches. It brings knowledge and wisdom, and is the force behind the power of goodness." 


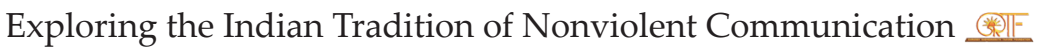

Further, if one reads the Bhagavad Gita, one finds important lessons on what should constitute healthy and ethical communication. Bhagavad Gita, Chapter 17, Stanza 15 says:

anudvega-karaḿ vākyaḿ

satyaḿ priya-hitaḿ ca yat

svādhyāyābhyasanaḿ caiva

vāń-mayaḿ tapa ucyate

Literally, it means, "Austerity of speech consists in speaking in a manner that will not agitate the minds of the listeners or enkindle the base emotions of the listener or his passion; the communication should be true, it must be beneficial to the listener and also pleasant. One should also engage in self-study (Balakrishnan, 2013).

Meanwhile Balakrishnan (2013) analyzes this Stanza which encompasses the essence of nonviolent communication:

1. It should not agitate the mind of the listener.

2. It should not in any way enkindle the base emotions of the listener.

3. It should be the truth.

4. It should be beneficial to the listener.

5. It should be pleasant to hear.

6. Such communications should be made only after through self-study.

Nonviolent verbal communication entails emotional bridge building and stresses on the essence of dialogue. In this context, Bhagavad Gita can be a classic example of continuous dialogue between Sree Krishna and Arjuna. If one carefully studies the dialogue between Sree Krishna and Arjuna, one would realize how both of them address each other by names which are dear to them. For instance, Arjuna addresses Sree Krishna as Achyuta, Kesava, Madhava Madhusudana etc. In response, Sree Krishna calls Arjuna as Partha, Kaunteya etc. This helps in emotional bridge-building, an important ingredient of nonviolent communication.

Again, for instance, if we take Bharat Muni's Natyashastra which is believed to have been composed around $100 \mathrm{BCE}$, this particular texttries to reflect upon the language and communication in Indian intellectual tradition. Commenting on the Natyashastra,

Vatsyayan (2016) observes, "Language must communicate at varying levels to different audiences in culture specific and transcultural contexts. While being in finite time and place, it must have power to communicate beyond time and place."

The Yoga Sutras of Patanjali also is an important treatise on nonviolent communication. For instance, Sutra II.36 (satya-pratișthāyạ̄̄ kriyā-phala-āśrayatvam) notes, "To one established in truthfulness, actions and their results become subservient." (https:// yogastudies.org/sutra/yoga-sutra-chapter-2verse-36/) According to Yoga Sutras, truth is based on the understanding that honest communication forms the basis for any relationship or community. The Yoga Sutras expresses concern that if we are untruthful, if we lie to others, then others will lie to us. Eventually, it notes that such a practice becomes normal to communicate through lying, never really saying what we mean or doing what we say.

Now it would be prudent to look at the essence of nonviolent communication in the Buddhist traditions. Nonviolence as per Buddhism can be understood primarily as non-hatred or non-illwill towards human or animals. An important form, nonviolence which the Buddhist tradition propagates is the essence of compassion. The Buddha's teaching starts with the four noble truths (catur-aryasatya). The first two truths discern the causes of violence and conflict and the suffering caused thereby: First, life inevitably involves suffering/dissatisfaction (duhkha-satya); and second, suffering/dissatisfaction originates in desires (samudaya-satya). The third and the fourth prescribe the cure for this unpleasant way of living, that is, how to promote a peaceful way of living and ultimately live-in peace: Third, suffering/dissatisfaction will cease if all desires cease (nirodha-satya); and Fourth, this state can be realized by engaging in the Noble Eightfold Path (marga-satya). 
In this backdrop, the Buddhist tradition eloquently puts the idea of nonviolent communication together in one of Buddha's eight-fold path, the right speech (sammāvāaca).The different ideas of right speech are:

$\odot$ It should be well-intended - comes from goodwill, not ill will; constructive; aimed to build up, not tear down

$\odot$ It should be true in nature - not overstated, taken out of context, or blown-up out of proportion

$\odot$ Aimed as the result should be beneficial - helps things get better, not worse (even if it takes a while)

$\odot$ It should not be harsh-It could be firm, pointed, or intense; it could confront mistreatment or injustice; anger could be acknowledged; but it is not prosecutorial, nasty, inflammatory, dismissive, disdainful, or snarky.

The importance of nonviolent communication can be emphasized by the fact that the Buddha mentioned it in his very first sutta after awakening,"The Discourse on Turning of the Wheel of Truth"(Dhammacakkappavattana Sutta). What then constitutes right speech? Magga-Vibhanga Sutta (SN 45:8) explains it, "And what is right speech? Abstaining from lying, abstaining from divisive speech, abstaining from abusive speech, abstaining from idle chatter."

Meanwhile the Subhasita-jaya Sutta SN11.5 says, "You make things worse, when you flare up, at someone who's angry. Whoever doesn't flare up at someone who's angry wins a battle hard to win... The victory through what is well spoken goes to Sakka the deva-king.'." (https://www. accesstoinsight.org/tipitaka/sn/sn11/sn11.005.than. html) This is definitely an important foundational stone of nonviolent verbal communication.

Vietnamese Zen Master, Thich Nhat Hanh's perspectives eloquently explains the importance of interconnectedness in all our action. Thich Nhat Hanh (1987) notes on his ideas of inter-being:

If you are a poet, you will see clearly that there is a cloud floating in this sheet of paper. Without a cloud, there will be no rain; without rain, the trees cannot grow; and without trees, we cannot make paper. The cloud is essential for the paper to exist. If the cloud is not here, the sheet of paper cannot be here either. We can say that the cloud and the paper inter-are. "Interbeing" is a word that is not in the dictionary yet, but if we combine the prefix "inter-" with the verb "to be," we have a new verb, "inter$b e " .$. Looking even more deeply, we can see we are in it too. This is not difficult to see, because when we look at a sheet of paper, the sheet of paper is part of our perception. Your mind is in here and mine is also, so we can say that everything is in here in this sheet of paper.

In this context, using Thich Nhat Hanh's notion of interbeing and engaged Buddhism, PhilipsAnderson (2017) points out, "In Nhat Hạnh's rhetorical nonviolence, the self and the other are simultaneous audiences. In rhetorical studies we are used to talking about multiple audiences for discourse. For Nhat Hạnh, all beings, in fact all creation, is part of the audience for every speech. This includes the speaker as an audience as well."

Thich Nhat Hanh (2013) explains how healthy communication is as important as the food we take and the air that we breadth in,"We tend to think of nourishment only as what we take in through our mouths, but what we consume with our eyes, our ears, our noses, our tongues, and our bodies is also food. The conversations going on around us, and those we participate in, are also food. Are we consuming and creating the kind of food that is healthy for us and helps us grow? When we say something that nourishes us and uplifts the people around us, we are feeding love and compassion. When we speak and act in a way that causes tension and anger, we are nourishing violence and suffering."

Nonviolent communication underlines the importance of looking at one idea from different perspectives or lenses. This has echo in all Indian traditions. For instance, the Jain doctrine of anekantvada (many sidedness or relative pluralism) also echoes with the pluralistic tradition of Indian communication ecosystem. This Jain doctrine helps us understand the principles of pluralism and the significance of multiplicity of viewpoints. The principle also teaches us that reality can be 


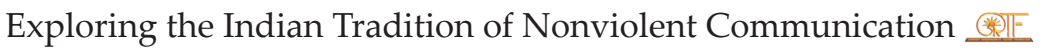

perceived and interpreted differently from diverse viewpoints. It helps us in realizing that no single view is the complete truth.

Further in Acarang Sutra, ahimsa has been described as:

Injurious activities inspired by self-interest lead to evil and darkness. This is what is called bondage, delusion, death, and hell. To do harm to others is to do harm to oneself. "Thou art he whom thou intendest to kill! Thou art he whom thou intendest to tyrranize over!" We corrupt ourselves as soon as we intend to corrupt others. We kill ourselves as soon as we intend to kill others. Ahimsa sprouts from a person's inner awakening" (Jain Gandhi, 2012).

Talking about Bhā ājāta (it. characteristic/s of speech), a chapter in the Acharang Sutra, Bhattacharya and Loho Choudhury (2016) points out how Bhā àjāta starts citing the types of speech that should be avoided," 1) Speech inspired by anger/ wrath; 2) Speech inspired by pride/ hubris; 3) Speech inspired by deceit/ deception; 4) Speech inspired by gain/ greed; 5) Speech with harshness both knowingly or unknowingly regarding the communicatee's position; 6) Speech reflecting positive/ certain hope regarding uncertain things.

This is a holistic perspective of ahimsa and underlines how it sprouts from a person's inner awakening. It also encompasses our communication ecosystem.

Nonviolent verbal communication has further been highlighted in different Indian texts and treaties. Thirukkural is one of the most important texts in Tamil written by Thiruvalluvar. In one of the texts, Thiruvalluvar says that a person should never employ a bad or filthy language to address another person. The language that we use, according to the text, should be pleasing for people to listen to. He devotes a complete chapter of 10 couplets on the importance of learning by listening, an important element of nonviolent verbal communication.

In modern times, echoing the Indian tradition of nonviolent verbal communication, Swami Vivekananda in his seminal speech, The Cosmos: the Microcosm, delivered on January 26, 1896 in New York noted, "The infinite future is before you, and you must always remember that each word, thought, and deed, lays up a store for you and that as the bad thoughts and bad works are ready to spring upon you like tigers, so also there is the inspiring hope that the good thoughts and good deeds are ready with the power of a hundred thousand angels to defend you always and forever."Here Swami Vivekananda stresses on the essence of good thoughts and good deeds which are an integral part of nonviolent verbal communication ecosystem (The Complete Works of Swami Vivekananda; Volume 2, Jnana-Yoga; Chapter XII).

\section{Exploring the Gandhian Model of Nonviolent communication}

The contemporary foundation of nonviolent communication in India which got major global traction was laid by Mahatma Gandhi. His approach of nonviolent communication stems from his five basic principles of nonviolence: respect, understanding, acceptance, appreciation and compassion (Gandhi, 2017).

Gandhi's vision of a nonviolent society was based on the 'cosmocentric view of human beings. Parekh (1997) explains the notion of cosmocentric view as followed by Gandhi:

The cosmos was a well-coordinated whole whose various parts were all linked in a system of yajna, or interdependence and mutual service. It consisted of different orders of being ranging from the material to the human, each governed by its own laws and standing in a complex relationship with the rest. Human beings were an integral part of the cosmos and were tied to it by the deepest bonds. In Gandhi's favourite metaphor, the cosmos was not a pyramid of which the material world was the base and the human beings the apex, but a series of ever-widening circles encompassing humankind, the sentient world, the material world, and the all including the cosmos.

According to Parekh(1997), Gandhi was clear that a nonviolent society, 'as human beings were interdependent, should discourage all forms of exploitation, domination, injustice, and inequality... and should find ways of institutionalizing and 
nurturing the spirt of love, truthfulness, social service, cooperation and solidarity'.

Parekh (1997) further delves on Gandhi's prescriptions of a nonviolent society which should 'cherish epistemological pluralism'. He notes: "It should appreciate that reason, intuition, faith, traditions intergenerationally accumulated collective wisdom, and emotions are all valuable sources of knowledge, and make their own distinct contributions to understanding and coping with the complexities of human life. The good society should encourage dialogue, a creative interplay between them, and not allow one of them to acquire a hegemonic role or become the arbiter of all others."

The Gandhian framework of nonviolent communication is based on the above cosmocentric view of human beings and his vision of a nonviolent society. The volume and expanse of Gandhi's nonviolent action and his prescriptions of a society was based on equality, justice and a nonexploitative paradigm. Gandhi's approach to communication was not just to reach out to the masses but also adroitly engaging them in constructive work. The tools of communication were used to wake up the millions out of their slumber and prepare them for one of the most powerful nonviolent struggles in world's history, the aim was to fearlessly face the exploitative British Raj and demand for political, social and economic justice. The constructive work which aimed at emancipating the poorest of the poor of the country was an integral part of his strategy of nonviolent verbal communication. Using his method of nonviolent communication and constructive work, he was able to develop a massive network of people across the length and breadth of India to oppose the British.

Gonsalves (2010) talks on Gandhi's conviction for the strategy 'to inject into the urban and rural illiterate masses and new mentality -fearlessness and a passion for independence.' Gonsalves notes, "He was convinced that only a communication strategy that was methodologically planned, hermeneutically relevant, creatively symbolic, morally disciplined, geographically extensive and founded uncompromisingly on satya and ahimsa would succeed."
The essence of constructive work as an integral part of Gandhi's communication strategy to reach out to the last person of the society has been aptly captured by Gandhi himself (Collected Works of Mahatma Gandhi, Vol 38, 311-12):

The volunteers are called upon to enlist themselves in order to do village reconstruction work, and this village reconstruction work is nothing but the organization of the peasantry and workers upon an economic basis. We want to enter into the hearts of the peasants. We want to identify ourselves completely with the masses. We want to make their woes our own. We want to feel with them in everything in order to better the lot of those on whose toil we the people of the city are really living. We must therefore make common cause with the workers.

Constructive work, hence, was a powerful tool of action communication wherein Mahatma Gandhi and the Gandhian constructive workers reached out to the last person of the society and identified themselves with their woes as their own.

Further, in order to reach out to the people, Gandhi used the strategies of padyatras or walking pilgrimage. This method of communication was actually an effort to encourage solidarity and struggle for justice through nonviolent means. During his lifetime, he and his followers undertook a large number of padyatras to connect with the masses.

The Gandhian principles of Satyagraha offers the guiding principles of nonviolent communication. The principles of Satyagraha necessitate that adversaries were never considered as eternal enemies but actually as potential friends. For a Satyagrahi, the object was 'not avoidance of all relationship with the opposing power' but the 'transformation of relationship'. Reaching out to one's opponents or those with whom we disagree is important when we think of resolving differences through strategies of nonviolent communication. In Gandhi's Satyagraha, in situations of dispute or differences, the aim should be to see the validity of the opponent's position and not push only one's point of view. The essence is to be empathetic in 
resolving differences. In Young India (19-3-1925), the Mahatma writing in this context says:

Immediately we begin to think of things as our opponent thinks of them, we shall be able to do them full justice. I know that this requires a detached state of mind, and it is a state very difficult to reach. Nevertheless, for a satyagrahi it is absolutely essential. Three-fourths of the miseries and misunderstandings in the world will disappear, if we step into the shoes of our adversaries and understand their standpoint. We will then agree with our adversaries quickly or think of them charitably.

In fact, the Gandhian model of nonviolent communication rests on the significance of nonviolent persuasion. This was an important attribute of Gandhi's satyagraha for reaching out to the adversaries. Here it would be pertinent to look at what nonviolent persuasion really constitutes of and in this context, Pelton (1974) noted, "An essential ingredient of nonviolent persuasion is the honest and straightforward dissemination of information... the withholding of information, the making of unsubstantiated charges...the packaging of an issue, and appeals to greed, prejudice and hatred cannot under any circumstances be reconciled with the philosophy of nonviolence."

Gandhi's communication principles have been well captured by Dr Rajendra Prasad, the first President of India who in his Introduction to the Collected Works of Mahatma Gandhi, paying homage to the Mahatma writes ('Homage', Collected Works of Mahatma Gandhi, Volume 1):

Here are the words of the Master covering some six decades of a superbly human and intensely active public life- words that shaped and nurtured a unique movement and let it to success; words that inspired countless individuals and showed them the light; words that explored and showed a new way of life; words that emphasized cultural values which are spiritual and eternal, transcending time and space and belonging to all humanity and all ages.

Meticulous use of nonviolent symbolism also formed part of Gandhi's communication strategy. In order to remain disciplined in his search for truth and ahimsa, Gandhi took a vow to observe silence on every Monday of the week. On the importance of silence, he notes in his Autobiography, "Proneness to exaggerate, to suppress or modify the truth, wittingly or unwittingly, is a natural weakness of man and silence is necessary in order to surmount it. A man of few words will rarely be thoughtless in his speech; he will measure every word."

Another powerful technique of nonviolent communication which Gandhi used was fasting. It was an effective method of nonviolent nonverbal persuasion. Used as a means of self-purification, he used this tool to convert the heart of the offender and also as a method to do penance for any wrong doing. Merriam (1975) talking on this nonviolent persuasion method points out, "Of all his techniques of symbolic action, the fast or hunger strike most typified Gandhi's character and temperament. Fasting afforded a method of influencing political policy and social attitudes by creating an emotional impact difficult to achieve through ordinary speech and negotiation. It also provided a source of spiritual renewal for a man dedicated to controlling his senses and desires."

Scholars like Bode (1995) have attempted to construct a Gandhian model of nonviolent communication. Bode notes, "For Gandhi, the goal of communication was to build and maintain human relationships and thus enhance personhood. Gandhi's insistence on nonviolence recognized the importance of others, valued humanity, and appreciated the importance of human relationships and personhood... Gandhi's nonviolent communication theory included the valuing of personhood throughout the world, but he also stressed the importance of individual relationships and friendships. ...Openness was manifested in Gandhi's rhetoric and is a characteristic of his nonviolent communication theory. For Gandhi, openness included communication practices such as free speech and press, public discussion, and direct negotiation."

In the context of the above understanding of the expansive nature of the Gandhian approach, his model of nonviolent communication can be constructed as an all-encompassing process. Based 
on these, it would be pertinent to delineate the important ingredients of the Gandhian model of nonviolent communication. These would include:

$\odot$ His model of nonviolent communication entails nonviolence in all aspects - verbal, nonverbal, thoughts and how the mind, heart and body remain disciplined at every stage.

$\odot$ Importance of nonviolent persuasion as an attribute of nonviolent verbal communication process.

$\odot$ Essence of nonverbal symbolism which aims at encouraging self-introspection and selfdiscipline, struggle for justice and emotionally connect with the people even the adversaries.

$\odot$ Gandhi's model of nonviolent communication encompasses principles of human interdependence and underlines the importance of the cosmocentric approach to human nature.

$\odot$ His strategy involved in reaching the hearts of the masses through constructive work for social and economic emancipation. This is an important dimension of nonviolent action communication.

$\odot$ The Gandhian model underlines the importance of empathy in all forms of communication. For instance, his Talisman is a powerful statement of how each individual need to introspect on what they are doing for the last person of the society- the essence of empathetic connections.

$\odot$ His five basic pillars of nonviolence- respect, understanding, acceptance, appreciation and compassion can be considered as foundational architecture of a nonviolent verbal communication ecosystem.

$\odot$ The Gandhian model entails the evolution of an individual to a higher plane of values and ethics and respect for human dignity.

$\odot$ His communication model underlines the importance of being morally disciplined, strictly adhering to the principles of ahimsa and truth, meticulous planning, creative and innovative, open and flexible.

Contemporary Gandhians have tried to use the Gandhian praxis of humanism to construct their own understanding of nonviolent communication. For instance, senior Gandhian, Natwar Thakkar gives an expansive understanding of what is nonviolent communication (Kundu, 2018):

To me nonviolent communication literacy would mean how our communication efforts should be nonviolent; how our ability and capacity to communicate not only with ourselves but with our family and society be nonviolent in all aspects and overall, how the entire process of communication whether between individuals, groups, communities and the world at large should be nonviolent in nature. This would entail deep understanding of the art and science of nonviolence and its centrality in all our daily actions. It's not just verbal and nonverbal communication, nonviolent communication literacy would also include whether our thoughts and ideas are nonviolent or not. This would also mean how we can rid of our preconceived notions of individuals or groups with whom we want to communicate and stop evaluating them to suit our own ideas. More than often, we are attuned to think in terms of moralistic judgments which may be our own constructions. By developing deep understanding of the art and science of nonviolence and integrating it in our communication practices we could get over with biased and moralistic judgments; this in turn could contribute to emotional bridge building.

\section{CONCLUSION}

The paper tried to develop understanding of the Indian tradition of nonviolent communication. It underlines how nonviolent communication has been an integral part of our ethos and ethical values. Also, it tried to construct a Gandhian model of nonviolent communication, a model which can be of great relevance in contemporary societies when the communication ecosystem in many occasions seem to become dysfunctional and leads to conflicts. While more research is needed in the area of Indian approaches to nonviolent communication, the aim should be to highlight these ideas not only at the national level but also at the global level. The ideas and dimensions of nonviolent communication should be integrated in our value 
systems, educational curriculum and in different organizational settings.

\section{REFERENCES}

Agrawala, V.S. 1963. The Thousand Syllabled Speech: Being a Study in Cosmic symbolism in its Vedic Version. Varanasi: Banaras Hindu University.

Balakrishnan, T.S. 2013. Effective Executive Communication, the Bhagavad Gita Way; IOSR Journal of Business and Management (IOSR-JBM), 13(4): 26-29.

Bhattacharyya, K.K. and Choudhury, B.L. 2016. Some Communication Thoughts in Jaina Philosophy; Media Mimansa; October-December 2016; (https://www.mcu. ac.in/media-mimansa/2016/October-December-2016/ mm-9-16.pdf)

Bode, Robert. A. 1995. Mahatma Gandhi's Theory of Nonviolent Communication; Paper presented at the Western States; Communication Association Conference; February 1995.

Gandhi, A. 2017. The Gift of Anger; Penguin Books.

Gonsalves, P. 2010. Clothing for Liberation: A Communication Analysis of Gandhi's Swadeshi Revolution; Sage.

Merriam, Allen H. 1975. Symbolic Action in India: Gandhi's Nonverbal Persuasion; Quarterly Journal of Speech, 61: 290.

Hạnh, T.N. 1987. Being peace. Berkeley, CA: Parallax Press.

Hanh, T.N. 2013. The Art of Communicating. Harper One.

Kundu, V. 2018. Nurturing Emotional Bridge Building: A Dialogue with Nagaland's Gandhi. Peaceworks, 8(1).
Jain, G. and Lal, S. 2012. The Jain Principle of Ahimsa (Nonviolence) and Ecology; Lecture delivered at the Institute of Oriental Philosophy on November 30, 2012; http://iop.or.jp/Documents/1323/Sohan\%20Lal\%20 Jain\%20Gandhi.pdf

Parekh, B. 1997. Gandhi: A Very Short Introduction; Oxford University Press.

Pelton, Leroy. H. 1974. The Psychology of Nonviolence; Pergamon.

Saraswati, D. 2015. Rigveda: Complete Translation, Vol. 1 (New Delhi: Hasananda).

Philips-Anderson, Michael \& Philips-Anderson, Rachel 2017. Writing a love letter to your (perceived) enemy: Thích Nhất Hạnh and the rhetoric of nonviolence; ESSACHESS. Journal for Communication Studies, 10(1): 73-90.

Sondhi, S. 2020. Sabdanusanam The Integral View of Communication; Kalakalpa, IGNCA Journal of Arts, Volume-IV, No.2, Basant Panchami, 2020.

The Complete Works of Swami Vivekananda; Volume 2, Jnana-Yoga; Chapter XII; The Cosmos , The Microcosm.

Tiwari, M. 2011. The Path of Practice: Healing with Food, Breath and Sound. Motilal Banarasidas Publishers: New Delhi, pp. 264.

Vatsyayan, K. 2016. Bharata: The Natyasastra. New Delhi: Sahitya Akademi. 
